\title{
SMART SOLUTIONS IN CITIES DURING THE COVID-19 PANDEMIC
}

\author{
Joanna Wyrwa, Magdalena Zaraś, and Katarzyna Wolak
}

\begin{abstract}
The COVID-19 pandemic has suddenly swept across the world on an unprecedented scale, having a global and destructive impact on numerous areas of both social and economic life. For the most part, the effects of the current pandemic crisis have been evaluated negatively, although they may also bring about positive future trends, such as accelerated technological advancement or increased financial support for and development of areas such as smart cities. Given the above, the focal point of our deliberations is the concept of smart cities and the exemplification of smart solutions implemented in cities in the context of new environmental challenges triggered by the COVID-19 pandemic. The purpose of the article is, on one hand, to identify the key theoretical and research problems that define the framework for smart city development, and on the other, to present selected practical smart projects implemented in different city areas in Poland and around the world during the COVID-19 pandemic. As far as the methodology, systematic literature analysis and case study have been opted for. To explain the essence of the smart city concept, Polish and foreign peer-reviewed scientific publications were analysed. To characterize smart solutions that are being implemented in different cities, findings from reports and materials retrieved from websites dedicated to smart initiatives were used. A search was carried out for scientific papers that contain the terms "smart city" and "COVID-19" in the title, abstract or among the keywords. Bibliometric analysis was the research method used to evaluate publications in terms of the smart city concept and the COVID-19 pandemic. To that end, research techniques such as trend analysis, citation analysis and word coexistence analysis were applied. In the article, selected issues of the smart cities functioning during a pandemic crisis are analysed. The findings show that cities have been keen on developing and implementing smart solutions during the COVID-19 pandemic, the latter obviously causing the accelerated development of smart-city systems. The pandemic-driven changes adopted so far by cities in the area of smart solutions are not only futureproof in terms of epidemic safety but also make other goals, such as limiting the use natural resources or increasing the quality of life for residents, more attainable.
\end{abstract}

Keywords: smart city, urban economy, city development, COVID-19, innovative projects, case study

JEL Classification: 01, 018, P25, Q55 


\section{Authors:}

\section{Joanna Wyrwa}

Faculty of Economics and Management University of Zielona Góra, ul. Podgórna 50, 65-246 Zielona Góra, Poland

E-mail: j.wyrwa@wez.uz.zgora.pl (corresponding author)

https://orcid.org/0000-0003-0837-6590

\section{Magdalena Zaraś}

Faculty of Economics and Management University of Zielona Góra, ul. Podgórna 50, 65-246 Zielona Góra, Poland

E-mail:96368@g.elearn.uz.zgora.pl

https://orcid.org/0000-0002-9070-1219

\section{Katarzyna Wolak}

Faculty of Economics and Management University of Zielona Góra, ul. Podgórna 50, 65-246 Zielona Góra, Poland

E-mail:96236@g.elearn.uz.zgora.pl

https://orcid.org/0000-0002-6224-7995

Citation: Wyrwa, J., Zaraś, M., \& Wolak, K. (2021). Smart Solutions in Cities during the Covid-19 Pandemic. Virtual Economics, 4(2), 88-103. https://doi.org/10.34021/ve.2021.04.02(5)

Received: March 12, 2021. Revised: March 26, 2021. Accepted: April 15, 2021.

(C) Author(s) 2021. Licensed under the Creative Commons License - Attribution 4.0 International (CC BY 4.0) 


\section{Introduction}

The COVID-19 pandemic suddenly swept across the world on an unprecedented scale, having a global and destructive impact on numerous areas of both social and economic life. The economic disruption caused by COVID-19 is not only destructive, but it also comes with side effects in the form of supply and demand shocks spanning virtually every area of human activity (Ozili \& Arun, 2020; Solarz \& Waliszewski, 2020; Kudełko et al., 2020). Since then, the classic concept of uncertainty often referenced by economic analysts has often been preceded by the word radical, thus becoming 'radical uncertainty'. With that, new terms have also emerged, such as: COVID-economy, post-COVID-economy, and coronomics (Stiglitz, 2021; van den Berg et al., 2021; Bhattacharya et al., 2020). The pandemic challenged the idea of progressive globalization and became a catalyst for change at a local and regional level. In the paper 'Proposals for Modification of Selected Economic Concepts Amid the COVID-19 Pandemic', the authors highlight a number of features of the COVID-19 pandemic which determine the specificity of its impact on the socioeconomic system as well as the features of the resulting crisis phenomena (Banaszyk et al., 2021, p. 58). Firstly, a pandemic carries the characteristics of the so-called "black swan", constituting an unexpected and unlikely event of far-reaching consequences. Secondly, the key indicators of crisis are: violence, deep recession, a sharp drop in GDP, employment rate, and others. Thirdly, tackling the negative economic impact of the pandemic has led governments and international organizations to intervene on an unprecedented scale. Last but not least, the difficulties associated with forecasting a postcrisis future and the reconstruction of the world economy must be noted as well.

The phenomena and processes that took place over the last two years were yet another confirmation that we are living in a time of epidemiological turbulence. For the most part, the effects of the current pandemic crisis have been evaluated negatively, although they may also bring about positive future trends, such as accelerated technological advancement or increased financial support for and development of areas such as smart cities. The smart city concept is a response to the global change regarding how cities are being built and managed, with an emphasis on their smartness regardless of how developed or underdeveloped they are. Such changes introduced over the course of the pandemic will not only increase epidemic safety in the future but will also help attain other goals such as limiting the use of natural resources or increasing the quality of life among residents.

The pandemic has forced local governments into an entirely new position requiring efficient crisis management and handling of pressing issues. And so, maintenance of critical infrastructure, including public utilities, public health, administration, public transport and public order has become their top priority very much overnight. The challenge was to adapt the existing systems to the current national restrictions. Provision of basic services required the adaptation of the work system to mind social distance, impossibility of face-to-face meetings and the need to protect vulnerable employees. This also meant a rapid digitization of offices as a prerequisite to keep the availability of public services unaffected. 
With the pandemic and the associated restrictions, urban areas that were once important to residents and visitors for business and leisure purposes suddenly became either inaccessible or less desirable compared to virtual solutions. The pandemic has also affected public mood and people's plans to live in cities, especially those who intend to keep working remotely even once the pandemic has been eradicated. Currently, an increasing number of city dwellers are considering moving outside the urbanized area. A London Assembly Housing Committee study reports that many Londoners are planning to abandon the capital in the next few years in order to move closer to nature as a direct result of the pandemic (Brodowicz, 2021, p. 55, 57). The same trend is observed in many cities around the world, and with each subsequent wave of the pandemic, it is bound to affect several areas of collective life. Due to numerous restrictions introduced in cities, solutions based on modern technologies have become crucial for the functioning of many institutions and the provision of municipal services.

In recent years, the issue of creating and developing smart cities has been systematically gaining ground, both in theoretical and practical terms. It should be noted here that more than half of the world population now live in cities (Vitunskaite et al., 2019; Kania, 2019, p. 72). For comparison, that number amounted to just 3\% at the end of the nineteenth century. Currently, according to the UN data, the global urbanization rate exceeds $50 \%$ and is expected to reach $60 \%$ by 2030 and $70 \%$ by 2050 (in the EU alone, it exceeded 68\% in 2018) (World Urbanization Prospects...). According to T. Kulisiewicz (2019, p. 136), the high population density in cities compared to suburban or rural areas intensifies social interactions, inducing economic, cultural and social undertakings. Large population combined with relatively high costs of living also create a sense of race among residents, as only the best and most innovative economic and social ideas and projects stand a chance. This gives rise to a positive feedback loop where the more innovative the urban community is and the better it fares, the more attractive it becomes, spawning increasingly innovative and creatively-minded community members who add to the competitiveness of that environment. It is therefore no surprise that current scientific debate on the development of urbanized areas increasingly often highlights the importance of smart cities (Ismagilova et al., 2019). At the same time, the issues discussed within the context of smart cities have always been interdisciplinary in nature, given that cities tend to encompass very diverse and varied elements (Szymańska \& Korolko, 2015). The vast majority of smart cities are spaces marked by an above-average technological, communication and IT literacy. Apart from technical and infrastructural matters, smart cities put a great emphasis on issues related to social, economic and environmental areas (Lazaroiu \& Roscia, 2012). It is not enough to simply embrace modern technologies, as the smart city concept covers a much broader range of needs (JonekKowalska, \& Wolniak, 2019). Some authors notice a vast source of urban intelligence springing from social capital, therefore making this prestigious group almost exclusive to big cities that are often either national or regional capitals (Stryjakiewicz \& Męczyński, 2015). A smart city is much less likely to be a small territorial unit and/or be located in a less urbanized or less economically developed area (Appio et al., 2019; Engelbert et al., 2019).

Given the above, the focal point of our deliberations is the concept of smart cities and the exemplification of smart solutions implemented in cities in the context of new environmental 
challenges triggered by the COVID-19 pandemic. The solutions most commonly referred to as 'smart' include, among others: e-office, smart boards in public facilities, video-powered mobile service points, smart stops, virtual and physical tools encouraging residents to help municipal services maintain order, remote learning platforms, community-building tools to look after those in need, smart buildings, smart environmental-monitoring systems, modern energy production solutions.

The concept of a "smart city", in addition to cross-disciplinary research, also has a specific practical dimension. Increasingly frequently it is reflected and accounted for in municipal strategies. International rankings of smart cities are regularly published, promoting the smartest and most resident-friendly urban living spaces (IESE Cities in Motion Index, 2020). Many researchers and main actors specializing in smart cities argue for a balanced approach to the creation and management of smart urban space. In this approach, infrastructural and economic issues are put on an equal footing with social and environmental ones. All parties are involved in the development of smart cities, in accordance with the Quintuple Helix model which encompasses: science, economics, community, environment, government at different levels, and the media.

The purpose of the article is, on one hand, to identify the key theoretical and research problems that define the framework for smart city development, and on the other, to present selected practical smart projects implemented in different city areas in Poland and around the world during the COVID-19 pandemic. The analysis carried out for the purposes of this study is explanatory and descriptive. As far as research methods used in the article are concerned, these are a critical literature review and a case study, which point to the qualitative nature of the study.

The article is descriptive and has been divided into two parts. In the first, theoretical part, the concept of a smart city was defined and its key properties were characterized. In the second, empirical part, the results of desk research aimed at presenting selected examples of smart solutions used during the COVID-19 pandemic were discussed.

The issues raised throughout the paper do not fully cover the problem area but constitute a premise for further research. The article can be used by both theoreticians and practitioners in the decision-making process in today's volatile economic conditions.

\section{Literature Review - Smart Cities in Theoretical Terms}

A 'smart city' is a complex concept covering the essence and importance of many aspects of urban development. The smart city concept attempts to approach urban development holistically, despite the fact that it refers to the multidimensional properties of cities (Mierzejewska, 2015). Researchers dealing with this subject matter emphasize different aspects of the smart city functioning. The concept has been studied and juxtaposed with technical, social, economic and environmental factors (Hajduk, 2020, p. 124). However, this also entails difficulties with unambiguously and precisely defining the concept (Bitkowska \& 
Łabędzki, 2021, p. 4; de Falco et al., 2019; Albino et al., 2015). One of the reasons for this inconsistent approach is the constantly accelerating advancement of new technologies, which makes the concept an evolutionary one (Mora \& Deakin, 2019). Another important determinant is the whole range of possibilities to adjust explanations on a city-to-city basis, which cannot be avoided given that cities differ not only in terms of the problems they face but also in their technological capacity to solve them (Łaźniewska, 2019, p. 105).

Initially, the smart city paradigm concerned information technologies that could be used for planning city development (Stawasz \& Sikora-Fernandez, 2016, p. 47). Subsequently, the concept evolved towards a city management method, the ability to attract high-class professionals or the ability to generate and absorb innovations (Florida, 2005).

According to the traditional definition, a smart city means introducing solutions based on the latest IT technologies to urban spaces with a view to improving the quality of life among their residents (Pięta-Kanurska, 2019, p. 60; Pięta-Kanurska, 2017, p. 185). It is a concept in which technological solutions make it possible to find a way out of the most pressing city-specific problems, such as improving the transport of persons and goods, counteracting climate change through the use of energy-efficient lighting, social inclusion (an accessible city).

The European approach to the smart city concept was originally based on activities related to the reduction of carbon dioxide emissions and activities aimed at effective use of energy in every area of city fabric while improving the quality of life of its residents (Stawasz \& SikoraFernandez, 2015, p. 18). Currently, as per the definition put forward by the European Commission, a smart city is the one which utilizes digital technologies to increase efficiency and improve living conditions, reduce costs and save resources, as well as boost civic engagement. The key sectors of a smart city include: transport, energy, health care, water and waste management. A smart city is also able to respond faster and better to any urban crises because of its high level of resilience (Ferrara, 2015). The EU documents emphasize the role of advanced technologies as a factor enabling the most effective response to the changing preferences and needs of city dwellers. Information and communication technologies (ICT) are therefore becoming tools for solving public problems with the participation of civil society. In the United States, the ICT sector is also seen as the key driver of the so-called power cities, while in Australia the role of digital media, creative industries and cultural initiatives are highlighted (Hollands, 2008).

The smart city concept is rooted essentially in three paradigms: (I) digital city, which uses ICT to support and network cooperation between citizens and organizations, exchange data and information, and implement online services such as e-government and e-democracy, (II) green city, with an ecological vision of urban space based on sustainable development and reduced environmental footprint, (III) knowledge-based city, relying on the enforcement and evaluation of data, information and knowledge available and produced within the city (after: Hajduk, 2020, p. 130; Benevolo et al., 2016). 
When trying to define smart cities, some authors emphasize the differences between smart and digital cities, pointing to the role of social and human capital, education, partnership and environmental factors as the main drivers of city growth. Regardless of the approach, both concepts are marked by a wealth of information processes, mechanisms that trigger creativity and boost absorptive capacity, and a sustainable approach to development. A city managed in line with the guidelines of the smart concept is a city of thoughtful and creative individuals who incorporate technical and technological innovations into their daily activities and who willingly use modern ICT solutions (Stawasz \& Sikora-Fernandez, 2016, p. 16). Caragliu et al. (2011) define a smart city as a city that invests in human and social capital, while the communication infrastructure leads to sustainable development and improved quality of life as a result of efficient natural resource management and participatory management. A smart city is primarily characterized by: a high level of governance (management) efficiency in conditions of uncertainty resulting from the use of innovative solutions, efficiency in creating knowledge, and high learning capacity. It is a city equipped with an extensive digital infrastructure, offering a broad range of e-services (including administrative), bringing together various creative-class individuals as well as being home to a number of R\&D institutions and universities. N. Komninos (after: Hajduk, 2020, p. 125) defines smart city as a creative-minded urban space with a high capacity to learn and introduce innovations. W. Mitchell (after: Kuzior \& Sobotka, 2019, p. 42), meanwhile, recognizes a smart city as a new dimension of the city derived from the combination of increasingly effective digital telecommunications networks (that can be compared to neurons), ubiquitous intelligence (compared to human brain), sensors and tags (compared to sensory organs), and software (compared to knowledge and cognitive skills). An important feature of smart cities is the fact that this new dimension does not exist in isolation from other current city systems - instead, it adds the layer of smartness to the existing network of overlapping links to mechanical and electronic systems found in buildings, embedded in household appliances (the Internet of Things), transport, electrical networks, water supply and sewage disposal networks, and ensuring the safety of its residents. According to R.G. Holland (2008, pp. 308-309), a smart city is an urban space focused on the use of transport and telecommunications infrastructure, ICT, and creative industries, while Albino et al. (2015) make a case for the following smart properties: network infrastructure reinforcing the effectiveness of political and cultural actions, development-promoting business and creative activities, social inclusion of city dwellers and engagement of social capital, natural environment.

An important issue regarding the definition and understanding of the smart city concept is the evolving approach to this concept due to the role of its main beneficiaries. And so, it is no longer enough for cities to focus on the implementation and use of modern technology, but they must also meet the needs of their beneficiaries in an optimal way, that is, so that the elements constituting the foundation of the smart city interact with each other and in so doing create a positive synergy (Albino et al., 2015). Three generations of smart cities are distinguished (Bitkowska \& Łabędzki, 2021, p. 5). In the first generation, advanced technologies play a fundamental role but the offered solutions are not adjusted to the specificity of the town. The authorities are most often unaware of the effects of the implemented technology and they neither raise these issues with the residents nor take the 
latter's expectations into account. Having said that, the same authorities play an important role in the second generation of smart cities, where they are actively involved and seek solutions best adapted to the specific need of their town. The lack of appropriate governance arrangements for most cities appears to be the most prominent obstacle to effectively becoming a smart city, even though state-of-the-art technologies support the pursuit of strategic goals and help improve the quality of life among residents. In the third generation, city dwellers themselves take the initiative and propose new solutions. Their ideas, expressed in the form of needs and expectations, are translated by providers of modern technologies into launchable projects. Here, the authorities either act as an assistant-observer or support the communication process. This civic engagement, however, cannot be one-off, and the residents are expected to forge a community that will be the source of new ideas and solutions.

Recently, authors have seemed to focus on combining the smart city concept with the participation of residents in the city management process, in particular making choices and implementing smart projects. In this sense, the idea of smart city defines the way the city is managed, with the relationships between the local government, IT suppliers, science and residents becoming particularly important (Pięta-Kanurska, 2019, p. 60).

Potential difficulties associated with determining the exact components of smart cities are the reason why there is no clear definition of this concept yet. Having said that, researchers seem to agree as to some of the areas that make up this concept. It is generally assumed that cities can be defined as smart if they meet the following criteria (Giffinger et al., 2007, pp. 10-11; Krysiński, 2020, p. 17, 158; Stawasz \& Sikora-Fernandez, 2015, pp. 19-20):

- smart economy - measured by the city's entrepreneurship and productivity, adaptation to changes, labour market flexibility, and international cooperation;

- smart mobility - measured as the local and supra-local availability of information and communication infrastructure through the development of a sustainable, innovative and safe transportation system;

- smart environment - measured as the attractiveness of the natural environment, the level of pollution, measures taken in the field of environmental protection and through resource management methods;

- smart people - characterized by the level of skills, lifelong learning, social and ethnic diversity, creativity, openness, and participation in public life;

- smart living - measured as the existing cultural facilities, living conditions (health, safety, housing), educational establishments, tourism potential, and social cohesion;

- smart governance - expressed by the transparency of city management, social participation, the level of public services and the implementation of development strategies.

The presence of at least one of the above characteristics is considered a prerequisite for including a city in the smart-city category. These correlate with traditional and neoliberal theories of urban and regional development, in particular in terms of competitiveness, quality of life, the significance of human and social capital, sustainable development and governance (Stawasz \& Sikora-Fernandez, 2016, p. 55). The systemization of fundamental smart areas in 
cities is an element of the comparative analysis of cities, which is carried out periodically by the Centre for Regional Research at TU Wien (http://www.smart-cities.eu/). These parameters are the basis for assessing the city in terms of its smartness, creativity and innovation, although most often in the case of smart cities, particular attention is paid to technological innovations. This systemization allows distinguishing two ways of describing a smart city: (1) a city based on ICT (Hollands, 2008) and (2) a new paradigm in city development in which human and social capital, education and the environment play a key role (Neirotti et al., 2014).

The technological trend is reflected, among others, in the definition of T. Bakici, E. Almirall and J. Wareham (Bakıcı et al., 2013) who perceive a smart city as "an intensive and technologically advanced city that connects people, information and city elements using new technologies to create a sustainable greener city, competitive and innovative trade and improved quality of life". Currently, the scientific discourse and local-government practice are dominated by the second trend, going far beyond the technocratic perception in which technological solutions play a merely supportive function. New technologies are instrumental in creating cities capable of combining physical and social capital, offering better services and quality infrastructure. These two smart-city perspectives are, by no means, contradictory, but rather should be seen as complementary.

The pandemic has shown how much ICT can facilitate city life, especially in the context of keeping social distance and limiting physical contacts between the community and public administration employees. Moreover, these technologies allow for the monitoring of densely populated areas in terms of disease spread. The existing untapped capabilities of ICT systems allow for remote body temperature measurement and data exchange in a centralized health care system. The ability to track infected individuals and those who had contact with them is equally important, as it enables their faster isolation and therefore curbs the spread of the pandemic (Wyrwich-Płotka, 2020, p.75).

\section{Methods}

Two research methods were used in the paper: a systematic literature review and a case study. Opting for a systematic review has not only allowed for a formalized objective synthesis and assessment of research to date (Columb \& Lalkhen, 2005), but more importantly, it has enabled the identification of both researched and as yet unexplored areas (Levy \& Ellis, 2006). This, in turn, provided a framework for further research (Gimenez \& Tachizawa, 2012) whose future findings could be generalized in the world literature (King, \& He 2005). In order to explain the essence of the smart city concept, Polish and foreign peer-reviewed scientific publications were analysed. A search was carried out for scientific publications that contain the terms "smart city" and "COVID-19" in the title, abstract or among the keywords. The review covers the years 2018-2021 and falls within the scope of social sciences. A bibliometric analysis was the research method used to evaluate publications in the area of the smart city concept and the COVID-19 pandemic. To that end, research techniques such as trend analysis, citation analysis and word coexistence analysis were applied. 
Choosing a case study as a research method was conditioned by several factors. Mainly it was the possibility of using a specific theoretical framework in the research process, in this case the smart city concept. This was further justified by the fact the case study method may cover different epistemological orientations and permits mixing quantitative and qualitative research techniques (Ćwiklicki \& Pilch, 2018). Another reason concerned being able to develop practical solutions on its basis. In this research, the instrumental case study was used - this is where the case plays an auxiliary role and it is selected because it illustrates an important research problem. The stages of the study were fashioned after W. Czakon (2016) and they were as follows: defining the purpose of the research, selecting cases, selecting data collection tools, collecting data, analysing data, forming generalizations, formulating conclusions. It should be noted that it was a pilot study that served as a trial preceding the actual research which is to cover a larger number of cases. The preparation of the theoretical part consisted in exploring secondary sources: previous studies, analyses and papers related to the smart city concept in connection with the COVID-19 pandemic published in scientific journals, both domestic and foreign. The study included a literature review where the current and prospective state of knowledge in this area were analysed. Lastly, to characterize smart solutions implemented in various areas across the cities, findings from reports and materials retrieved from websites dedicated to smart initiatives were used.

\section{Results and Discussion - Examples of implementing the smart city concept in selected cities during the COVID-19 pandemic}

The smart city concept is becoming increasingly important. Originally, a smart city meant a city where smart technology is implemented to streamline the provision of municipal services. Over time however, the concept was expanded to include new elements: smart people, smart governance, smart environment, smart mobility, smart living, smart economy (according to the European Smart City Index). These new dimensions of the smart city concept mean that it is evolving rapidly, with many cities indeed putting it into practice. Examples of smart cities show that these are areas marked by high mobility of its residents and green solutions that help reduce the emission of carbon dioxide and other pollutants into the environment. The implementation of smart products and services in these cities prompts new elements to emerge and be subsequently incorporated into the concept. The advancement in the implementation of the smart city paradigm varies for different cities.

A smart city is fostered by people and it is precisely the concern for their safety during the COVID-19 pandemic that has been prioritized. The smart city concept allows for an innovative approach to everyday matters which has now become more important than ever before. Smart-city projects are being carried out all over the world. In this part of the article, the most prominent examples of using smart solutions during the COVID-19 pandemic will be discussed, along with an outline of how this concept is being applied and which solutions have helped ensure public safety during the current pandemic. 


\subsection{The on-going smart-city projects in Warsaw during the COVID-19 pandemic}

Smart solutions in Warsaw are intended primarily to improve the quality and comfort of residents' life. The smart city technology is being used in areas such as public transport, air quality, green areas, or city budget. There are a number of mobile applications in Warsaw to help commuters purchase public-transit tickets, pay for city parking, check departure times, plan routes, or estimate expected times of buses or trams' arrival based on the real-time vehicle location. In addition, there are several dozens of electric buses operating in Warsaw and an order was placed for another 140 . In the coming years, Poland's capital aims to replace its fleet with electric and gas-propelled vehicles and install public charging stations for individual drivers. Warsaw, with its strong base of incubators and various forms of business support, is becoming a prominent hub for entrepreneurship, innovation and start-ups of all sorts. This is influenced by a number of initiatives taken by the public, private and science sectors (report developed by the City of Warsaw, Warsaw Heading Towards a Smart City). One such example is the e-inspection of paid parking zones - on 7 January 2020, two electric Nissan cars for the first time travelled the streets of Warsaw's unguarded parking zones to scan license plates and report violations. These inspections are aimed at effectively reducing the number of foot patrols (E-Kontrola działa. Rusza trzecie auto, 2021). Furthermore, through the installation of appropriate devices and the use of infrastructure management applications, the intelligent district heating network in Warsaw enables an optimized use of resources and an annual carbon footprint has been reduced by at least 14,500 tons, which is equivalent to planting one million trees. During the pandemic, remote diagnostics of network status was launched to avoid direct contact with media recipients (report developed by the City of Warsaw, Warsaw Heading Towards a Smart City). Additionally, Librus and the e-notebook for schoolteachers support remote learning in the times of the pandemic. ProtegoSafe is an application that monitors the surroundings in search of other devices on which it is installed, logging every meeting that exceeds 15 minutes and is held at a distance of less than 2 meters. If any of the users falls sick, other users with whom they had contact in the last 14 days will be notified accordingly. Due to this, they can better protect themselves and others (Ewaluacja realizacji koncepcji Smart City w państwach Grupy Wyszehradzkiej, 2021).

\subsection{The on-going smart-city projects in Valencia during the COVID-19 pandemic}

A novel, creative approach adopted by Generalitat Valenciana (the Valencia Region Government) currently champions the practical application of various fields of knowledge dealing with space, among them being: architecture, civil engineering, urban planning, spatial planning, as well as different branches of art and public communication and management. Generalitat Valenciana provides a global data exchange platform and implements a policy framework for the smart management of public health crises in cities. Valencia has launched the Frena La Curva initiative, a citizens' platform to drive and manage social resilience to the COVID-19 pandemic, providing a bottom-up response complementing government action and the work of public services. In a few months' time, citizens across Spain offered and provided over 9,000 free public services. Social-action innovation, the collaborative approach and the active participation of citizens are the key factors behind the success of this initiative (Smart 
Cities have responded to COVID-19, 2020). The Sharing Cities program, consisting in the farreaching modernization of energy buildings, recognizes that the zero-carbon targets will be achieved not only through top-down policies but will also require bottom-up action by local beneficiaries, including citizens. Solutions developed under Sharing Cities, such as the Digital Social Market, are intended to encourage citizens to positively change their behaviour towards meeting the targets of sustainable development.

\subsection{The on-going smart-city projects in New York during the COVID-19 pandemic}

Big data, which analyses vast and diverse data sets, is being utilized in increasingly surprising ways. It was big data that during the COVID-19 pandemic allowed selecting nearly 160 kilometres of roads within New York City which could be excluded from traffic without causing additional traffic jams to offer residents additional space to walk, bike or rest while maintaining social distance ("Big data" rewolucjonizuje zarządzanie, Nowy Jork przykładem, 2013). The City of New York allocated over $\$ 200$ million to improve access to fibre optic networks for residents. In addition, the authorities also purchased several thousand tablets to be used, among others, by students in remote learning settings (New York Smart Cities Innovation Partnership). Interestingly, New York did not restrict access to museums or public facilities over the course of the pandemic. Safety protocols in those establishments are being monitored by special sensors attached to clothes which emit sounds whenever the distance between two people inside the building is too small. Excelsior Pass is a blockchain-based application designed by IBM as a virtual wallet for storing medical records. According to IBM, the blockchain technology that was used is interoperable, which means that similar passes could be used by other state or local agencies in the future. New York is additionally piloting a COVID-19 digital vaccine passport that would allow its holders - via a digital card stored in their phones - to present proof that they have been vaccinated against COVID-19 and/or have tested negative for the virus (Smart cities walczą z pandemią, 2020).

\section{Conclusions}

This article aims to present the smart city concept in both theoretical and practical terms. D. Brodowicz (2021) points out that people are the backbone of any smart city in which numerous smart solutions have been introduced in recent years - from cloud services, to solutions used in medicine or in everyday life. State-of-the-art technologies used in urban areas have significantly improved the life of the community as a whole - especially during the COVID-19 pandemic.

All modern technologies previously used in cities seemed to be viewed mostly as gadgets, whereas now with the pandemic, they have gained enormous importance to the point of becoming very much indispensable. There is also no doubt as to the fact that the pandemic accelerated the development of smart-city systems in many urban areas. Most experts agree that such solutions are here to stay and be improved, which will provide a further boost to smart cities. Changes related to the smart city concept that were introduced during the pandemic will not only allow for greater epidemiological safety in the future, but will also 
enable the implementation of the goals set for smart cities. One such example is the increased quality of life for city residents or limiting the use of natural resources. COVID-19 caught the public off guard, but it quickly became apparent that effective remote living was indeed possible. Of course, it would not have been so without using the solutions borrowed from smart cities.

The conducted review of the literature and of selected examples of implementing smart solutions by different cities around the world shows that the meaning of the smart city concept is multifaceted and complex, and the measurement of its advancement is complicated at best. It therefore seems important to try and further systematize knowledge in the field of the smart city concept in order to facilitate its implementation and better monitor how it evolves. Further research is needed to define the role of smart cities in the context of smart solutions implemented in urban areas during the pandemic.

\section{References}

Albino, V., Berardi, U., \& Dangelico, R.M. (2015). Smart Cities: Definitions, Dimensions, Performance, and Initiatives. Journal of Urban Technology, 22(1), 3-21. https://doi.org/10.1080/10630732.2014.942092.

Appio, F.A., Lima, M., \& Paroutis, S. (2019). Understanding Smart Cities: Innovation ecosystems, technological advancements, and societal challenges. Technological Forecasting \& Social Change, 142, 1-14. https://doi.org/10.1016/j.techfore.2018.12.018.

Bakıcı, T., Almirall, E., \& Wareham, J. (2013). A Smart City Initiative: The Case of Barcelona. Journal of the Knowledge Economy, 4, 135-148. https://doi.org/10.1007/s13132-012-0084-9.

Banaszyk, P., Deszczyński, P., Gorynia, M., \& Malaga, K. (2021). Przesłanki modyfikacji wybranych koncepcji ekonomicznych na skutek pandemii COVID-19 [Proposals for Modification of Selected Economic Concepts Amid the COVID-19 Pandemic]. Gospodarka Narodowa. The Polish Journal of Economics, 1, 53-86.

Benevolo, C., Dameri, R.P., \& D'Auria, B. (2016). Smart Mobility in Smart City. In: T. Torre, A.M. Braccini \& R. Spinelli (eds.), Empowering Organizations. Lecture Notes in Information Systems and Organisation (pp. 13-28). Cham: Springer International Publishing. https://doi.org/10.1007/978-3319-23784-8 2.

Bhattacharya, T.R., Bhattacharya, A. Mclellan, B., \& Tezuka, T. (2020). Sustainable smart city development framework for developing countries. Urban Research \& Practice, 13(2), 180-212. https://doi.org/10.1080/17535069.2018.1537003.

"Big data" rewolucjonizuje zarządzanie, Nowy Jork przykładem (2013). Retrieved from https://www.pb.pl/big-data-rewolucjonizuje-zarzadzanie-nowy-jork-przykladem-715848

Bitkowska, A., \& Łabędzki, K. (2021). Koncepcja inteligentnego miasta - definicje, założenia, obszary [The Concept of Smart City - Definition, Assumptions, Areas]. Marketing i Rynek, 2, 3-11. 
Brodowicz, D.P. (2021). Inteligentne rozwiązania w miastach w czasie pandemii - wybrane obszary, funkcje i zastosowania [Smart solutions in cities during a pandemic - selected areas, functions and applications]. e-mentor, 1, 55-63.

Caragliu, A., Del Bo, C., \& Nijkamp, P. (2011). Smart Cities in Europe. Journal of Urban Technology, 18(2), 65-82. https://doi.org/10.1080/10630732.2011.601117.

Columb, M.O., \& Lalkhen, A.G. (2005). Systematic Reviews \& Meta-Analyses. Current Anaesthesia \& Critical Care, 16(6), 391-394.

Ćwiklicki, M., \& Pilch, K. (2018). Rygor metodologiczny wielokrotnego studium przypadku w badaniach marketingu miejsc [Methodological Rigour of Multiple Case Study Research in Place Marketing]. Studia Ekonomiczne. Uniwersytet Ekonomiczny w Katowicach, 376, 23-35.

Czakon W. (2016). Zastosowanie studiów przypadku w badanych nauk o zarządzaniu. In: W. Czakon (ed.), Podstawy metodologii badań w naukach o zarzqdzaniu (pp. 189-210). Warszawa: Wydawnictwo Nieoczywiste.

de Falco, S., Angelidou, M., \& Addie, J-P.D. (2019). From the "smart city" to the "smart metropolis"? Building resilience in the urban periphery. European Urban and Regional Studies, 26(2), 205-223. https://doi.org/10.1177/0969776418783813.

E-Kontrola działa. Rusza trzecie auto (2021). Retrieved from https://zdm.waw.pl/aktualnosci/ekontrola-dziala-rusza-trzecie-auto/

Engelbert, J., van Zoonen, L., \& Hirzalla, F. (2019). Excluding citizens from the European smart city: The discourse practices of pursuing and granting smartness. Technological Forecasting \& Social Change, 142, 347-353. https://doi.org/10.1016/j.techfore.2018.08.020.

Ewaluacja realizacji koncepcji Smart City w państwach Grupy Wyszehradzkiej (2021). Retrived from: https://www.ewaluacja.gov.pl/media/101590/Ewaluacja_smart_city_V4.pptx

Ferrara, R. (2015). The Smart City and the Green Economy in Europe: A Critical Approach. Energies, 8, 4724-4734. https://doi.org/10.3390/en8064724.

Florida, R. (2005). Cities and the Creative Class. London: Routledge.

Giffinger, R., Kalasek, R., Fertner, C., \& Milanović, N.P. (2007). Smart cities - Ranking of European medium-sized cities. Vienna: Centre of Regional Science (SRF), Vienna University of Technology.

Gimenez C., \& Tachizawa, E. (2012). Extending Sustainability to Suppliers: A Systematic Literature Review. Supply Chain Management: An International Journal, 17(5), 531-543.

Hajduk, S. (2020). Modele smart city a zarządzanie przestrzenne miast [Smart City Model and Urban Spatial Management]. Gospodarka Narodowa. The Polish Journal of Economics, 2, 123-139.

Hollands, R.G. (2008). Will the real smart city please stand up? Intelligent, progressive or entrepreneurial? City, 12(3), 303-320. https://doi.org/10.1080/13604810802479126.

IESE Cities in Motion Index (2020). Retrieved from https://blog.iese.edu/cities-challenges-andmanagement/2020/10/27/iese-cities-in-motion-index-2020/

Ismagilova, E., Hughes, L. Dwivedi, Y.K., \& Ravi Raman, K. (2019). Smart cities: Advances in research An information systems perspective. International Journal of Information Management, 47, 88100. https://doi.org/10.1016/j.jijinfomgt.2019.01.004. 
Jonek-Kowalska, I., \& Wolniak, R. (2019). Holistyczne podejście do rozwoju inteligentnych miast [Holistic approach to the development of smart cities]. In: I. Jonek-Kowalska (ed.), Wyzwania $i$ uwarunkowania zarzqdzania inteligentnymi miastami (pp. 23-40). Gliwice: Wydawnictwo Politechniki Śląskiej.

Kania, A. (2019). Koncepcja smart city w budowaniu konkurencyjności nowoczesnego miasta na przykładzie Mannheim w Niemczech [The Smart City Concept in Building the Competitiveness of a Modern City on the Example of Mannheim in Germany]. Biuletyn Polska Akademia Nauk. Komitet Przestrzennego Zagospodarowania Kraju, 273, 71-83.

King W. R., \& He J. (2005). Understanding the Role and Methods of Meta-Analysis in IS Research. Communications of the Association for Information Systems, 16, 665-686.

Krysiński, P. (2020). Smart city w przestrzeni informacyjnej. Toruń: Wydawnictwo Naukowe Uniwersytetu Mikołaja Kopernika.

Kudełko, J., Wałachowski, K., \& Żmija, D. (2020). Gospodarka regionalna w obliczu kryzysu wywołanego pandemiq COVID-19. Warszawa: Difin.

Kulisiewicz, T. (2019). Transformacja miasta w miasto inteligentne - wyzwania dla administracji publicznej [Transformation into the Smart City: challenges for city administration]. Roczniki Kolegium Analiz Ekonomicznych. Szkoła Główna Handlowa, 56, 133-147.

Kuzior, A., \& Sobotka, B. (2019). Społeczny wymiar smart city [Social aspect of smart city]. In: I. JonekKowalska (ed.), Wyzwania i uwarunkowania zarzqdzania inteligentnymi miastami (pp. 41-55). Gliwice: Wydawnictwo Politechniki Śląskiej.

Lazaroiu, G.C., \& Roscia, M. (2012). Definition methodology for the smart cities model. Energy, 47, 326332. http://dx.doi.org/10.1016/j.energy.2012.09.028.

Łaźniewska, E. (2019). Istota koncepcji smart city. Aktywność miasta Poznania na drodze do smart city [The essence of the Concept of a Smart City. The activity of the City of Poznan leading to a Smart City]. Rozwój Regionalny i Polityka Regionalna. Instytut Geografii Społeczno-Ekonomicznej i Gospodarki Przestrzennej Uniwersytetu im. Adama Mickiewicza w Poznaniu, 48, 105-117.

Levy, Y., \& Ellis, T.J. (2006). A Systems Approach to Conduct an Effective Literature Review in Support of Information Systems Research. Informing Science Journal, 9, 181-212. https://doi.org/10.28945/479.

Mierzejewska, L. (2015). Zrównoważony rozwój miasta - wybrane sposoby pojmowania, koncepcje i modele [Sustainable development of a city: selected theoretical frameworks, concepts and models]. Problemy Rozwoju Miast, 3, 5-11.

Mora, L., \& Deakin, M. (2019). Smart city development in Europe. In: Untangling Smart Cities. From utopian dreams to innovation systems for a technology-enabled urban sustainability (135-170). https://doi.org/10.1016/C2017-0-02666-6.

Neirotti, P., De Marco, A., Cagliano, A.C., Mangano, G., \& Scorrano, F. (2014). Current trends in Smart City initiatives: Some stylised facts. Cities, 38, 25-36. http://dx.doi.org/10.1016/j.cities.2013.12.010.

New York Smart Cities Innovation Partnership. Retrieved from: https://esd.ny.gov/new-york-smartcities-innovation-partnership 
Ozili, P.K, \& Arun, T. (2020). Spillover of COVID-19: Impact on the Global Economy. http://dx.doi.org/10.2139/ssrn.3562570.

Pięta-Kanurska, M. (2017). Wehikuły rozwoju współczesnych miast. Wyzwania dla Wrocławia [Development Vehicles of Modern Cities. Challenges for Wrocław]. Studia KPZK, 177, 182-202.

Pięta-Kanurska, M. (2019). Smart city a rozwój inkluzywny [Smart City and Inclusive Growth]. Biuletyn Polska Akademia Nauk. Komitet Przestrzennego Zagospodarowania Kraju, 273, 59-70.

Smart Cities have responded to COVID-19 (2020). Retrieved from https://smart-citiesmarketplace.ec.europa.eu/news-and-events/news/2020/smart-cities-have-responded-covid-19

Smart cities walczą z pandemią (2020). Retrieved from https://300gospodarka.pl/materialpartnera/smart-cities-walcza-z-pandemia-material-partnera

Solarz, J.K., \& Waliszewski, K. (2020). Całościowe zarzqdzanie ryzykiem systemowym Pandemia COVID19. Kraków: Wydawnictwo edu-Libri.

Stawasz, D., \& Sikora-Fernandez, D. (2015). Koncepcja smart city w teorii i praktyce zarządzania rozwojem miast. In: D. Stawasz \& D. Sikora-Fernandez (eds.), Zarzq̨dzanie w polskich miastach zgodnie z koncepcjq smart city (pp. 11-29). Warszawa: Wydawnictwo Placet.

Stawasz, D., \& Sikora-Fernandez, D. (2016). Koncepcja smart city na tle procesów i uwarunkowań rozwoju współczesnych miast. Łódź: Wydawnictwo Uniwersytetu Łódzkiego.

Stiglitz, J.E. (2021). The proper role of government in the market economy: The case of the post-COVID recovery. Journal of Government and Economics, 1, 100004. https://doi.org/10.1016/j.jge.2021.100004.

Stryjakiewicz, T., \& Męczyński, M. (2015). Klasa kreatywna w dużym mieście [Creative Class in a Big City]. Rozwój Regionalny i Polityka Regionalna. Instytut Geografii Społeczno-Ekonomicznej $i$ Gospodarki Przestrzennej Uniwersytetu im. Adama Mickiewicza w Poznaniu, 31, 97-109.

Szymańska, D., \& Korolko, M. (2015). Inteligentne miasta - idea, koncepcje i wdrożenia. Toruń: Wydawnictwo Naukowe Uniwersytetu Mikołaja Kopernika.

van den Berg, M., Debernardini, G., \& Lelijveld, A. (2021). COVID-19 impact study: assessing the consequences of the pandemic on economic output in developing countries for targeted sectors. Enterprise Development \& Microfinance, 32(1), 68-77. https://doi.org/10.3362/1755-1986.2100018.

Vitunskaite, M., He Y., Brandstetter, T., \& Janicke, H. (2019). Smart cities and cyber security: Are we there yet? A comparative study on the role of standards, third party risk management and security ownership. Computers\&Security, 83, 313-331. https://doi.org/10.1016/j.cose.2019.02.009.

World Urbanization Prospects: The 2018 Revision. Retrieved from https://population.un.org/wup/Publications/

Wyrwich-Płotka, S. (2020). Praca zdalna jako element koncepcji inteligentnego miasta [Teleworking as an Element of the Smart City Concept]. Studia Miejskie, 39, 71-81. 